\title{
Upaya Peningkatan Teknik Dasar Sepak Bola Melalui Metode Permainan Beregu pada Siswa Sekolah Menengah Pertama
}

\author{
Sardianto \\ SMP Negeri 1 Mojosongo, Boyolali
}

\begin{abstract}
Abstrak
Tujuan penelitian ini adalah : (1) Untuk meningkatkan hasil belajar teknik dasar sepak bola (2) Untuk meningkatkan hasil belajar teknik dasar sepak bola melalui permainan beregu. Metode penelitian yang digunakan untuk mencapai tujuan di atas adalah metode pembelajaran Penilaian Tindakan Kelas (PTK). Penelitian ini dilaksanakan di SMPN 1 Mojosongo Boyolali Tahun Pelajaran 2019/ 2020. Sampel diambil sebanyak 40 siswa yang dikelompokkan ke dalam dua siklus. Pelaksanaan Perlawanan (treatmen) diberikan selama delapan minggu dan dilaksanakan secara bertahap dengan mengerjakan program pembelajaran yang telah ditentukan. Data dikumpulkan dengan teknik free test dan post test. Hasil metode permainan beregu dapat diambil dengan teknik dasar sepak bola. Penelitian ini menyimpulkan bahwa : (1) Melalui permainan beregu dapat meningkatkan teknik dasar sepak bola bagi siswa kelas VIII A SMPN 1 Mojosongo Kabupaten Boyolali (2) Melalui permainan beregu dapat meningkatkan keaktifan peserta didik kelas VIII A SMPN 1 Mojosongo Kabupaten Boyolali (3) Pembelajaran teknik dasar sepak bola melalui permainan beregu pada pokok pembahasan teknik dasar sepak bola dapat meningkatkan ketuntasan belajar teknik dasar sepak bola.
\end{abstract}

Kata Kunci: metode permainan beregu, teknik dasar sepak bola, siswa sekolah menengah pertama

\section{The Efforts of Improving Basic Football Techniques through Team Play Methods for Middle School Students}

\author{
Sardianto \\ SMP Negeri 1 Mojosongo, Boyolali
}

\begin{abstract}
The objectives of this study are: (1) To improve learning outcomes of basic soccer techniques (2) To improve learning outcomes of basic soccer techniques through team games. The research method used to achieve the above objectives is the Classroom Action Assessment (CAR) learning method. This research was conducted at SMPN 1 Mojosongo Boyolali in the 2019 Academic Year. The sample was taken as many as 40 students who were grouped into two cycles. Implementation of the Resistance (treatment) is given for eight weeks and carried out in stages by working on a learning program that has been determined. Data collected by free test and post test techniques. The results of the team play method can be drawn using basic soccer techniques. This study concludes that: (1) Through team games can improve the basic techniques of soccer for students of class VIII A at SMPN 1 Mojosongo in Boyolali Regency (2) Through team games can increase the activity of students in class VIII A at SMPN 1 Mojosongo in Boyolali Regency (3) Learning basic soccer techniques through team games on the subject of basic soccer techniques can improve the mastery of learning basic soccer techniques.
\end{abstract}

Keywords: team play methods, basic soccer techniques, junior high school students 


\section{PENDAHULUAN}

Setiap kegiatan yang dilakukan oleh guru maupun siswa mempunyai tujuan, untuk itu perlu dipikirkan bagaimana alat peraga yang digunakan sesuai agar dalam waktu yang relatif terbatas dapat tercapai tujuan pendidikan yang diinginkan. Pada kenyataan yang ada hasil belajar teknik dasar sepak bola di kelas VIII A SMPN 1 Mojosongo Boyolali belum menggembirakan karena rata-rata nilai pada ulangan harian masih di bawah 65, sejalan dengan pelaksanaan Kurikulum Tingkat Satuan Pendidikan (KTSP) salah satu upaya yang dilakukan di sekolah adalah penggunaan media pembelajaran yang tepat bagi siswa kelas VIII A SMPN 1 Mojosongo Boyolali. Hal ini harus dilaksanakan agar kebutuhan nilai tersebut dapat tercapai dengan baik sesuai tuntutan Kurikulum 2013 pada sistem pendidikan berbasis kompetensi penjasorkes khususnya teknik dasar sepak bola siswa kelas VIII A SMPN 1 Mojosongo Boyolali diharapkan bermanfaat sebagai kerangka dasar fungsi kurikulum 2013. Kurikulum 2013 dapat berjalan secara kreatif, inovatif, efektif, menyenangkan dan bermakna bagi perserta didik. Perubahan dan implementasi itu tidak hanya konsep metode dan strategi guru dalam mengajar akan tetapi situasi dan kondisi siswa juga harus kondusif dan menyenangkan, sehingga siswa merasa nyaman belajar di sekolah.

Salah satu cara untuk pembelajaran dalam rangka meningkatkan hasil belajar teknik dasar sepak bola adalah dengan media atau memanfaatkan alat bantu yang sesuai. Menurut pengalaman guru bidang studi penjasorkes khususnya Kelas VIII A SMPN 1 Mojosongo Kabupaten Boyolali sangat efektif untuk mencapai peningkatan hasil belajar teknik dasar sepak bola. Dan uraian tersebut di atas disimpulkan bahwa perlunya diadakan Penelitian Tindakan Kelas (PTK) terhadap penggunaan alat bantu dan media yang tepat karena dapat memenuhi nilai atau fungsi media pembelajaran secara umum. Berdasarkan latar belakang tersebut, maka judul yang dipilih dalam penelitian ini adalah “Upaya Peningkatan Hasil Belajar Teknik Dasar Sepak Bola Melalui Metode Permainan Beregu Siswa SMPN 1 Mojosongo kelas VIII A Kabupaten Boyolali Tahun Pelajaran 2019/ 2020".

Berdasarkan latar belakang tersebut di atas, maka dapat dimunculkan rumusan masalah sebagai berikut : pertama, bagaimana permainan beregu dapat meningkatkan 
hasil belajar teknik dasar sepak bola?. Kedua, apakah melalui permainan beregu dapat meningkatkan keaktifan peserta didik? Ketiga, apakah melalui permainan beregu dapat meningkatkan ketuntasan klasikal bagi siswa kelas VIII A semester genap SMP Negeri 1 Mojosongo Kabupaten Boyolali?.

Tujuan penelitian ini diharapkan dapat : pertama, menemukan peningkatan hasil belajar teknik dasar sepak bola kelas VIII A semester genap di SMPN 1 Mojosongo Boyolali Kabupaten Boyolali yang lebih efektif. Kedua, meningkatkan keaktifan siswa melalui permainan beregu. Ketiga, mengetahui sejauhmana pengaruh metode permainan beregu dapat meningkatkan ketuntasan teknik dasar sepak bola bagi siswa SMP Negeri 1 Mojosongo Kabupaten Boyolali

Hakekat teknik dasar sepak bola dengan metode permainan beregu dalam proses belajar mengajar (PBM), utamanya dalam pendidikan olah raga dan kesehatan merupakan salah satu komponen yang mutlak harus ada. Hal tersebut dapat dimungkinkan karena tanpa adanya teknik dasar, maka proses belajar mengajar tidak akan berjalan sesuai dengan tujuan yang diharapkan. Sejalan dengan penelitian Maria (2019), bahwasanya untuk mecampai ketuntasan belajar diperlukan suatu upaya mempermudah siswa dalam belajar entah itu metode atau media.

Permainan beregu dalam proses belajar mengajar untuk melakukan sesuatu pelajaran dalam upaya menyampaikan gagasan baru, sehingga gagasan itu sampai pada si penerima (audiensi) sedangkan media adalah sebuah perantara yang digunakan untuk menyampaikan gagasan atau ide-ide baru, sehingga ide-ide itu sampai pada si penerima.

Berdasarkan kajian teori diatas, maka dapat diajukan hipotesis tindakan sebagai berikut: pertama, melalui pernanfaatan permainan beregu dapat meningkatkan belajar teknik dasar sepak bola bagi siswa kelas VIII A SMPN 1 Mojosongo Kabupaten Boyolali Tahun Pelajaran 2019/2020. Kedua, pembelajaran teknik dasar sepak bola melalui metode permainan beregu dapat meningkatkan keaktifan belajar peserta didik kelas VIII A SMPN 1 Mojosongo Kabupaten Boyolali. Ketiga, pembelajaran teknik dasar sepak bola melalui metode permainan beregu pada pelaksanaan bahasan teknik dasar sepak bola kelas VIII A SMPN 1 Mojosongo Kabupaten Boyolali 


\section{METODE}

Penelitian ini merupakan penelitian tindakan kelas (classroom action research) yang di tandai dengan adanya siklus, adapun dalam penelitian ini terdiri atas 2 (dua) siklus, adapun dalam penelitian ini terdiri atas perencanaan (planning), pelaksanaan (acting), pengamatan (observing) dan refleksi (reflecting).

Rancangan siklus 1: Perencanaan (Planning) terdiri atas kegiatan : a) Penyusunan rencana pelaksanaan pembelajaran (RPP), b) Penyiapan scenario pembelajaran. Pelaksanaan (acting): a) Pelaksanaan program pembelajaran siswa dengan jadwal, b) proses pembelajaran dengan menerapkan keragaman, kemampuan di kelas khususnya ban bekas, c) memilih sarana/ prasarana pendukung kegiatan belajar Teknik Dasar Sepak Bola dengan memanfaatkan permainan beregu, d) Perlengkapan permainan beregu. Pengamatan (observing) yaitu mengamati proses pembelajaran dan menilai hash tes, sehingga diketahui hasilnya atas dasar hasil tersebut yang akan dipergunakan untuk merencanakan tindak lanjut pada siklus berikutnya. Refleksi (reflecting) yaitu menyimpulkan pelaksanaan hash tindakan pada siklus satu.

Rancangan Siklus 2 : Perencanaan (Planning) terdiri atas: a) melakukan identifikasi hasil refleksi siklus I, b) merumuskan tindakan dan solusi. Pelaksanaan (Acting): a)Membagi siswa dalam kelompok, b) melakukan pembelajaran Teknik Dasar Sepak Bola dengan metode permainan beregu. Pengamatan (Observing) : Setiap kemajuan yang terjadi pada proses pembelajarann pada siklus II diadakan observasi. Dari observasi kemudian dievaluasi untuk diteliti dan dicari kelemahan dan kelebihan sebagai dasar menentukan langkah tindakan berikutnya. Refleksi (Reflecting) Melakukan refleksi secara kolaborasi dengan hasil sebagai berikut: a) Siswa sudah mulai terbiasa dengan menggunakan permainan beregu, b) guru mengetahui kelemahan siswa dan berusaha memperbaikinya. c) Siswa melakukan pembelajaran dengan senang dan sudah mulai aktif dalam melakukan pembelajaran dengan mernanfaatkan permainan beregu serta mulai aktif dalam mengeluarkan pendapat pada saat berdiskusi. 
www.journal.univetbantara.ac.id/index.php/ijimm

\section{HASIL DAN PEMBAHASAN}

Kemampuan awal hasil belajar teknik dasar sepak bola yang diperoleh dari ulangan harian. Sebelum dilakukan tindakan memanfaatkan permainan beregu.

Tabel 1. Hasil belajar teknik dasar sepak bola sebelum metode permainan beregu

\begin{tabular}{cccc}
\hline Nilai & Jumlah $(\mathrm{F})$ & N. F & Prosentase \\
\hline 50 & 5 & 250 & $12,5 \%$ \\
55 & 4 & 220 & $10,0 \%$ \\
60 & 6 & 360 & $45,5 \%$ \\
65 & 8 & 520 & $20,0 \%$ \\
70 & 7 & 490 & $17,5 \%$ \\
75 & 6 & 450 & $15,0 \%$ \\
80 & 4 & 320 & $10,0 \%$ \\
85 & - & - & - \\
Jumlah & 40 & & $2130: 40=53,26 \%$ \\
Rerata & & $23: 40 \times 100 \%=57,5 \%$ \\
Ketuntasn Klasikal & & &
\end{tabular}

Data tabel 1 dapat dilihat kondisi awal sebelum diberi tindakan. Dalam hal ini nilai Teknik Dasar Sepak Bola yang diperoleh dalam kegiatan belajar mengajar sebelum menggunakan alat bantu bans bekas, nilai diperoleh melalui tes yang dilaksanakan oleh guru mata pelajaran. Hasil belajar awal (pra siklus) Teknik Dasar Sepak Bola siswa kelas VIII A SMPN 1 Mojosongo Boyolali dapat digambarkan grafik sebagai berikut.

Grafik 1 Hasil belajar teknik dasar sepak bola pada pra siklus

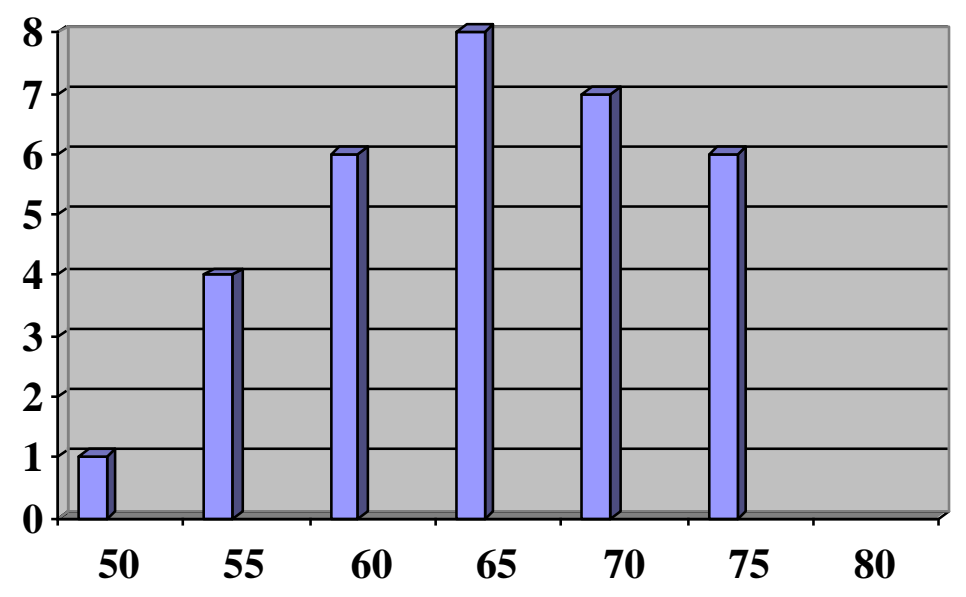


Pada keadaan awal dapat dilihat nilai rata-rata teknik dasar sepak bola 53,26\% siswa yang mendapat nilai dibuat sebanyak 6 siswa atau 15,0\% sedang siswa yang telah mencapai batas tuntas yakni mendapat nilai 60 ke atas sebanyak 14 siswa atau 35,0\% dan prosentase tersebut berarti sebagian besar siswa belum mencapai hasil yang memuaskan dan paling banyak ada siswa mendapatkan 55 berjumlah 6 siswa atau 15,0\%. Berdasarkan hasil belajar teknik dasar sepak bola masih rendah, maka sebagai guru mata pelajaran berusaha melakukan inovasi pembelajaran agar hasil belajar teknik dasar sepak bola dapat ditingkatkan/ inisiatif yang diambil guru mata pelajaran serta di dukung Kepala Sekolah yang dibantu teman guru kolaborasi dilakukan inovasi pembelajaran dengan metode permainan beregu tujuan untuk meningkatkan hasl belajar teknik dasar sepak bola.

Setelah dilaksanakan penelitian melalui tindakan kelas, pada siklus I diperoleh hasil seperti berikut:

Tabel 2. Hasil belajar teknik dasar sepak bola setelah metode permainan beregu pada siklus 1

\begin{tabular}{cccc}
\hline Nilai & Jumlah $(\mathrm{F})$ & N. F & Prosentase \\
\hline 50 & 5 & 250 & $12,5 \%$ \\
55 & 4 & 385 & $17,5 \%$ \\
60 & 6 & 420 & $17,5 \%$ \\
65 & 8 & 455 & $17,5 \%$ \\
70 & 7 & 420 & $15,0 \%$ \\
75 & 6 & 375 & $12,5 \%$ \\
80 & 4 & 240 & $7,5 \%$ \\
Jumlah & 40 & 2545 & $100 \%$ \\
Rerata & \multicolumn{3}{c}{$2545: 40=63,63 \%$} \\
\hline Ketuntasn Klasikal & \multicolumn{3}{c}{$28: 40 \times 100 \%=70,0 \%$}
\end{tabular}

Dari tabel 2 diatas dapat dilihat kondisi siklus 1 setelah diberi tindakan. Dalam hal ini berupa nilai tolak peluru yang diperoleh dalam kegiatan belajar mengajar melalui pemanfaatan bola besar, nilai diperoleh melalui tes yang dilaksanakan oleh guru mata pelajaran. Hasil belajar penjasokes khususnya Teknik Dasar Sepak Bola kelas VIII A 
SMPN 1 Mojosongo Kabupaten Boyolali pada siklus 1 melalui metode permainan beregu dapat digambarkan dalam bentuk grafik sebagai berikut :

Grafik 2 Hasil belajar teknik dasar sepak bola siklus 1

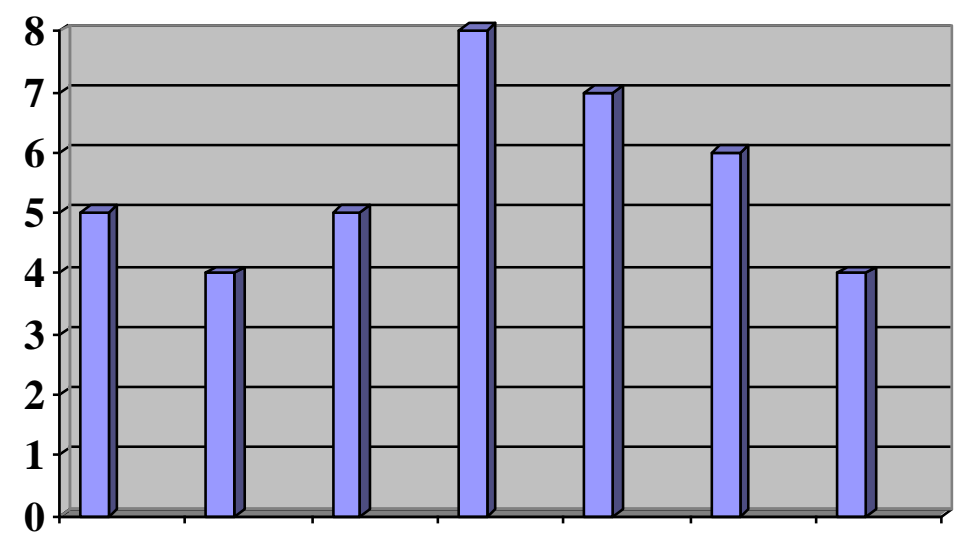

Pada siklus 1 dopat dilihat rata-rata teknik dasar sepak bola $53,26 \%$. Siswa yang mendapatkan nilai di bawah 60 sebanyak 9 siswa atau 22,5\%. Sedangkan siswa yang telah mencapai batas tuntas yaitu mendapatkan nilai 60 ke atas sebanyak 31 siswa atau 77,5\%. Dari prosentase tersebut berarti siswa belum mencapai hasil yang memuaskan dan paling banyak adalah siswa mendapat nilai 65 berjumlah 8 siswa atau 20,0\%. Berdasarkan hasil belajar teknik dasar sepak bola yang belum mencapai batas tuntas adalah 9 siswa, maka guru mata pelajaran terus berusaha melakukan inovasi pembelajaran agar hasil belajar Teknik Dasar Sepak Bola dapat ditingkatkan. Inisiatif yang diambil guru mata pelajaran serta didukung oleh Kepala Sekolah dan dibantu teman kolaborasi, melanjutkan inovasi pembajaran dengan memaksimalkan alat bantu yaitu membenahi segala kekurangan yang ada guru memamfaatan alat bantu dengan tujuan pada siklus berikutnya hasil belajar teknik dasar sepak bola dapat ditingkatkan dan dapat mencapai batas tuntas yang ditentukan yakni 65 keatas.

Setelah dilanjutkan tindakan kelas pada siklus II, hasil belajar teknik dasar sepak bola siswa kelas VIII A SMPN 1 Mojosongo Boyolali, Kabupaten Boyolali yang dalam pembelajaran yang memanfaatkan alat bantu dapat disajikan dalam bentuk tabel sebagai berikut. 
www.journal.univetbantara.ac.id/index.php/ijimm

Tabel 3. Hasil belajar teknik dasar sepak bola setelah menggunakan metode permainan beregu pada siklus 2 (Sumber data : Lampiran)

\begin{tabular}{cccc}
\hline Nilai & Jumlah (F) & N. F & Prosentase \\
\hline 50 & 2 & 100 & $0,05 \%$ \\
55 & 3 & 168 & $0,75 \%$ \\
60 & 5 & 300 & $12,5 \%$ \\
65 & 7 & 455 & $17,5 \%$ \\
70 & 8 & 560 & $20,0 \%$ \\
75 & 7 & 525 & $17,5 \%$ \\
80 & 8 & 640 & $20,0 \%$ \\
Jumlah & 40 & & \\
Rerata & \multicolumn{3}{c}{$2748: 40=68,72 \%$} \\
Ketuntasan Klasikal & \multicolumn{3}{c}{30 x $100 \%=75 \%$} \\
\hline
\end{tabular}

Hasil prestasi belajar penjasorkes melalui metode permainan beregu siswa kelas VIII A SMPN Mojosongo Kabupaten Boyolali pada siklus 2 dapat digambarkan bentuk grafik sebagai berikut :

Grafik 3 Hasil belajar teknik dasar sepak bola siklus 2

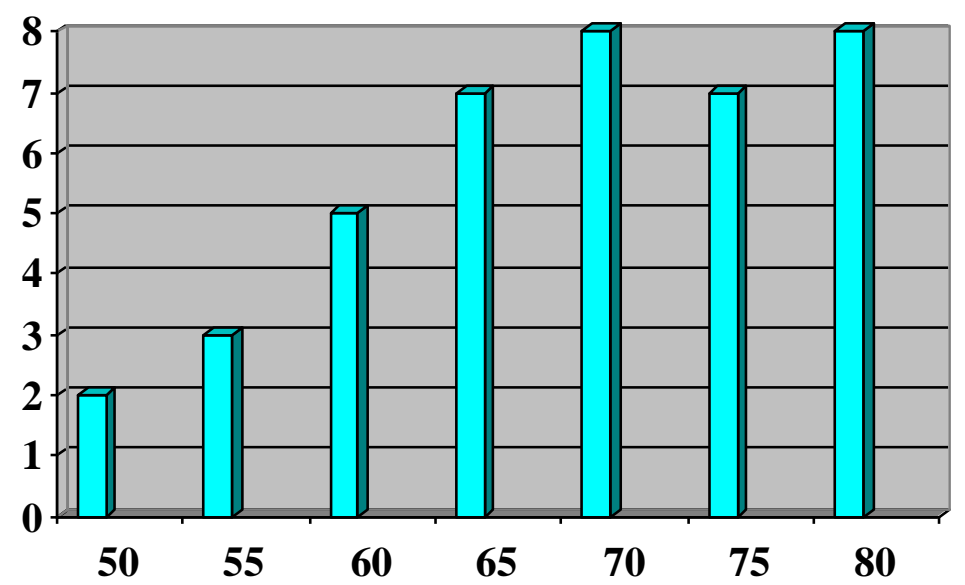

Pada siklus 2 dapat dilihat nilai rata-rata teknik dasar sepak bola 68,7\% yang 
mendapat nilai di bawah 60 tinggal 4 siswa atau $0,1 \%$. Sedangkan siswa telah mencapai batas tuntas yaitu mendapat nilai 60 ke atas sebanyak 30 siswa atau 75\%. Dari prosentase tersebut berarti sebagian siswa telah mencapai hasil yang memuaskan dan paling banyak adalah siswa mendapat nilai 80 berjumlah 8 siswa atau $20 \%$.

Berdasarkan hasil presentasi belajar teknik dasar sepak bola yang telah mencapai batas tuntas, maka guru kelas tetap harus berusaha melakukan inovasi pembelajaran agar hasil belajar teknik dasar sepak bola dapat dipertahankan dan dapat ditingkatkan. Inisiatif yang diambil guru kelas serta di dukung oleh Kepala Sekolah dan dibantu teman kolaborasi, melanjutkan inovasi pembelajaran dengan meningkatkan hasil belajar teknik dasar sepak bola yaitu memberikan semangat kepada siswa untuk senantiasa selalu aktif dalam pembelajaran untuk mendiskusikan dengan teman guru, meningkatkan kerjasama yang baik dengan tujuan hasil belajar Teknik Dasar Sepak Bola dapat ditingkatkan termasuk untuk mata pelajaran yang lainya.

Berdasarkan data awal hasil belajar teknik dasar sepak bola, diketahui rata-rata sebesar 10\% terdapat 4 siswa nilai kurang dari 60 dan 30 siswa mendapat nilai 60 keatas. Ketuntasan secara klasikal sebesar 75,0\%. Berdasarkan data tersebut, rata-rata kelas belum mencapai batas tuntas yang ditetapkan. Demikian pula secara klasikal belum mencapai ketuntasan.

Berdasarkan hasil tes pada siklus 1 diketahui rata-rata nilai penjasorkes pembelajaran teknik dasar sepak bola sebesar 67,5\% didapatkan sebanyak 34 siswa mendapat nilai di bawah 60 (belum tuntas belajarnya) dan terdapat 37 siswa yang telah tuntas, karena mendapatkan nilai 60 ke atas. Ketuntasan secara klasikal telah mencapai 75,0\%. Berdasarkan data tersebut, secara klasikal belum mencapai ketuntasan belajar.

Berdasarkan hasil tes pada siklus 2, diketahui rata-rata nilai penjasorkes materi teknik dasar sepak bola sebesar $68,5 \%$ terdapat 7 siswa yang telah mendapat nilai 60 atau lebih (tuntas belajarnya) tinggal 10 siswa yang belum tuntas karena mendapat nilai di bawah 65 walaupun dilihat dari peningkatan telah menunjukkan peningkatan yang signifikan. 
Ketuntasan secara klasikal telah mencapai $75,0 \%$. Berdasarkan data tersebut, secara klasikal telah mencapai ketuntasan belajar.

Berdasarkan hasil observasi dengan upaya-upaya perbaikan yang dilakukan pada pembelajaran Teknik Dasar Sepak Bola, hasil yang dicapai siswa mengalami peningkatan. Peningkatan tersebut dapat dilihat daru naiknya presentase hasil tes yang diperoleh siswa.

Tabel 4. Hasil belajar teknik dasar sepak bola pada kondisi awal Siklus 1 dan siklus 2

\begin{tabular}{ccccccc}
\hline \multirow{2}{*}{ Nilai (N) } & \multicolumn{2}{c}{ Kondisi awal } & \multicolumn{2}{c}{ Siklus I } & \multicolumn{2}{c}{ Siklus 2 } \\
\cline { 2 - 7 } & Jumlah & $\%$ & Jumlah & $\%$ & Jumlah & $\%$ \\
\hline 50 & 5 & $12,5 \%$ & 5 & $12,5 \%$ & 1 & $2,5 \%$ \\
55 & 4 & $10,0 \%$ & 7 & $17,5 \%$ & 3 & $0,75 \%$ \\
60 & 6 & $45,5 \%$ & 7 & $17,5 \%$ & 6 & $12,5 \%$ \\
65 & 8 & $20,0 \%$ & 7 & $17,5 \%$ & 8 & $17,5 \%$ \\
70 & 7 & $17,5 \%$ & 6 & $15,0 \%$ & 8 & $20,0 \%$ \\
75 & 6 & $15,0 \%$ & 5 & $12,5 \%$ & 8 & $17,5 \%$ \\
80 & 4 & $17,5 \%$ & 3 & $25 \%$ & 6 & $20,0 \%$ \\
Jumlah & 40 & $100 \%$ & 40 & $100 \%$ & 40 & $100 \%$ \\
Rata-rata & $2130: 40=53,26$ & $2545: 40=63,64$ & $2765: 40=69,12$ \\
Ketuntasan klasikal & $23: 40 X 100=57,5 \%$ & $28: 40 X 100=70,0 \%$ & $30: 40 X 100=75 \%$ \\
\hline
\end{tabular}

Dari hasil nilai rata-rata dari setiap siklus dapat dibuat tabel perbandingan sebagai berikut.

Tabel 5. Rekapan hasil belajar teknik dasar sepak bola pada kemampuan awal Siklus 1 dan siklus 2

\begin{tabular}{ccc}
\hline Siklus & Nilai Rata-Rata & Peningkatan \\
\hline Kemampuan awal & 13,26 & \\
Siklus I & 63,64 & 10,38 \\
Siklus II & 69,12 & 54,8 \\
\hline
\end{tabular}


Dari hasil peningkatan nilai Teknik Dasar Sepak Bola siswa kelas VIII A SMPN 1 Mojosongo Kabupaten Boyolali tersebut di atas dapat digambarkan dalam bentuk grafik sebagai berikut :

Grafik 4 Hasil belajar teknik dasar sepak bola siklus I dan siklus II

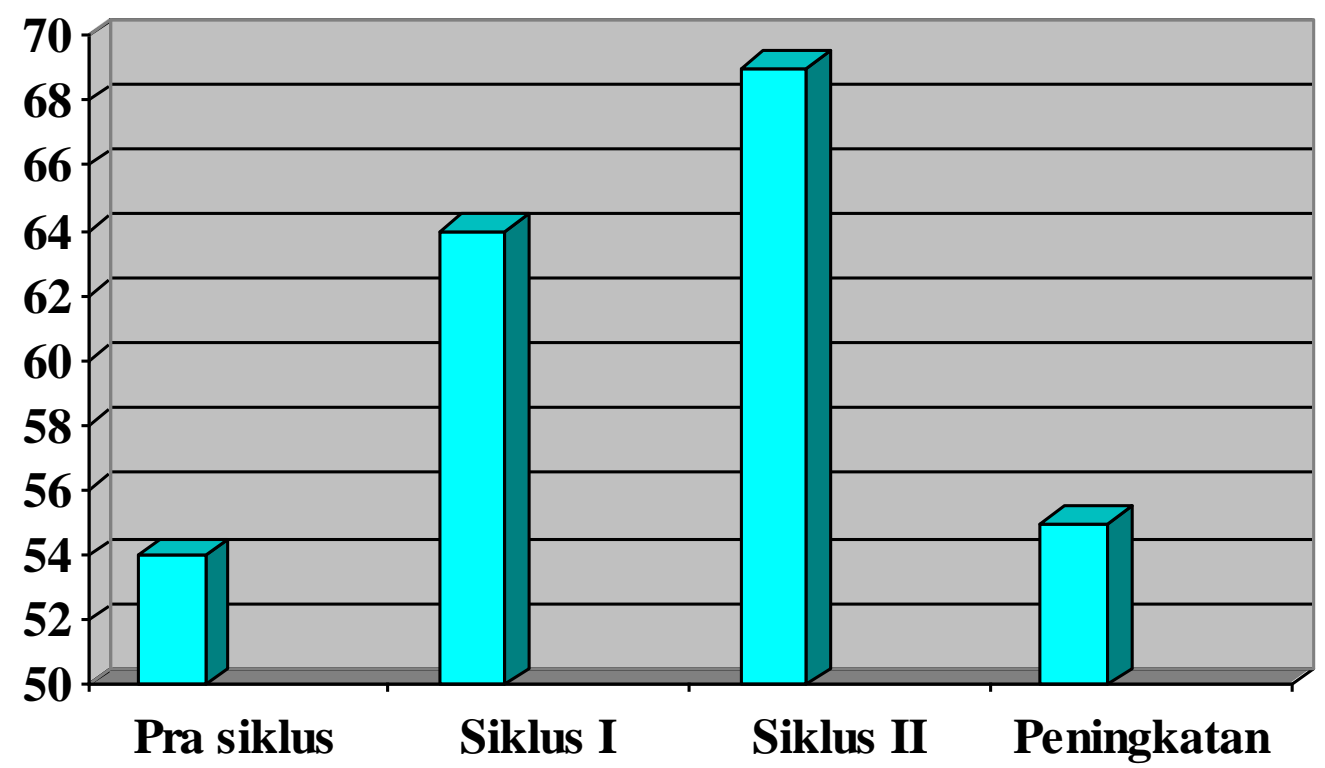

Berdasarkan indikator kinerja yang telah ditetapkan bahwa hasil belajar teknik dasar sepak bola siswa kelas VIII A SMPN 1 Mojosongo Kabupaten Boyolali tuntas ditentukan apabila 5\% dari jumlah siswa mendapatkan nilai 60 ke atas. Dari hasil tindakan melalui metode permainan beregu dapat diketahui jumlah siswa mendapat nilai 65 ke atas mencapai 75,0\% sehingga diasumsikan bahwa sebagian besar siswa telah menuntaskan mata pelajaran teknik dasar sepak bola dan tinggal 5 siswa atau $12.5 \%$ yang belum menuntaskan mata pelajaran teknik dasar sepak bola, tetapi dilihat dari peningkatan prestasi yang dicapai setiap siklus terdapat peningkatan yang signifikan, ini dapat dimaklumi karena faktor-faktor yang mempengaruhi prestasi belajar dapat berasal dari dalam diri siswa yang meliputi : tingkat intelegensi, minat belajar, motivasi belajar, dan lain-lain. Hasil penelitian ini bila dengan teori masih relevan. Prestasi belajar dipengaruhi oleh beberapa faktor baik intern maupun ekstern. Teori ini pun sejalan dengan hasil yang dilakukan sari (2019), menjelasakan bahwasanya tinggi rendahnya motivasi belajar siswa 
berpengaruh terhadap prestasi belajar siswa.

Media alam sekitar termasuk faktor yang berasal dari luar diri siswa yang mempengaruhi hasil belajar teknik dasar sepak bola, hal ini dapat dimaklumi karena manfaat sebagaimana yang dikemukakan Arif S. Sadiman (2003 : 7) yaitu : memperjelas penyajian pesan agar tidak terlalu bersifat verbalistis, menimbulkan kegairahan belajar, memungkinkan interaksi yang lebih langsung antara siswa dengan guru dan memungkinkan siswa belajar sendiri-sendiri menurut kemampuan, bakat dan minatnya.

\section{SIMPULAN}

Setelah diadakan analisis Ada yang diperoleh dari penelitian maka dapat disimpulkan sebagai berikut: pertama, memanfaatan permainan beregu dapat meningkatkan hasil belajar Teknik Dasar Sepak Bola bagi siswa kelas VIII A SMPN 1 Mojosongo Kabupaten Boyolali Tahun Pelajaran 2019/2020. Kedua, berdasarkan indikator yang telah ditetapkan bahwa hasil belajar teknik dasar sepak bola siswa kelas VIII A SMPN 1 Mojosongo Kabupaten Boyolali tuntas belajar, apabila $80 \%$ dari jumah siswa mendapat nilai 60 keatas. Dari hasil tidakan melalui pemanfaatan permainan beregudan dapat diketahui jumlah siswa mendapat nilai 60 keatas mencapai 90,9\% sehingga di asumsikan pelajar teknik dasar sepak bola siswa telah menuntaskan pelajaran teknik dasar sepak bola dan tinggal 2 siswa atau 9,10\% belum menuntaskan pelajaran teknik dasar sepak bola tetapi dilihat dari peningkatan yang dicapai setiap siklus terdapat peningkatan yang dicapai setiap siklus terdapat dari peningkatan yang dicapai setiap siklus terdapat peningkatan yang signifikan pada setiap siswa. Ketiga, permainan beregu dapat meningkatkan hasil belajar teknik dasar sepak bola bagi siswa kelas VIII A SMPN 1 Mojosongo Kabupaten Boyolali mempunyai kenaikan masing-masing $75 \%$. 
www.journal.univetbantara.ac.id/index.php/ijimm

\section{DAFTAR REFERENSI}

Arief, S Sadiman dkk. 2003. Metode Pendidikan. Jakarta. Rajawali.

Depdikbud. 1997, Pusat Kesegaran Jasmani dan Rekreasi, Jakarta.

Gunter, Benhard, 1993, Atletik, Jakarta: Efther \& Dahara Prize Offset.

Harsono, 1998, Coaching dan Aspek-aspek dalam Coaching, Jakarta.

Jorach, U, Hagy.E. Krempel R, 1998, Atletik I, Jakarta : PT. Rosida Jaya Putra Offset.

Maria Laestisia. (2019). Meningkatkan Hasil Belajar IPS melalui Model Pembelajaran Problem Based Instruction di Sekolah Dasar. Indonesian Journal of Instructional Media and Model, 1(2),63-73.

Oemar, H. Malik. 2000. Metode Belajar dan Kesulitan Belajar. Bandung. Transito

Sari, A. Y. (2019). Meningkatkan Motivasi dan Prestasi Belajar Matematika melalui Model Pembelajaran Think-Pair-Share. Indonesian Journal of Instructional Media and Model, 1(1),1-9.

Sukatamsi,1995, Sepak Bola, Teori dan Praktek Atlet I, Surakarta : Depdikbud, Universitas Sebelas Maret.

Mirdiyanto, 2011. Atletik. Teori Praktik, Semarang : Depdikbud Universitas Negeri Semarang 